\title{
Comparative Botanical Studies on Some Trifoliate Plants Belonging to the Subfamily Faboideae in Egypt
}

\author{
Hamza, M.K. ${ }^{(1)}$, Sahar, F. El-Hefnawy ${ }^{(2)}$, El-Taher, A. M. ${ }^{(1)}$ and Shahinaz, El-Shahat ${ }^{(1)}$ \\ (1) Dept. of Agricultural Botany, Fac. of Agric., Al-Azhar Univ., Cairo, Egypt. \\ ${ }^{(2)}$ Dept. of Biological and Environmental Science, Fac. of Home Economic Al-Azhar Univ., Tanta. \\ Corresponding author: shmariam69@yahoo.com
}

\begin{abstract}
Papilionoideae (Faboideae) is the largest subfamily in the family Leguminosae. The study occure on some trifoliate species belonging to this subfamily. The investigations include the morphological characters of the vesgetative organs(stems and leaves) beside the micromorphological features obtained from the examinations of the leaflets epidermis (cell walls shape,trichomes forms, stomatal types and the precense or absence of oxalate crystals).Also the study includes floral aspects and the type and shapes of fruits and seeds.
\end{abstract}

Keywords: Stem, leaves, flowers, stomata, fruits, seeds, Faboideae , morphology

\section{Introduction}

The subfamily Papilionoideae (Faboideae) is the largest subfamily in the Leguminosea which comprises over 13,800 species, many of which are important as food crops Miller et al. (2011). Habit of Psoralea is perennial herbs and subshrubs; habit of Phaseolus vulgaris is annual herbs, Meikle (1985). Habit of Cajanus cajan is shrub habit of Melilotus indica is herb with apubescent biennial, habit of Trigonella foenum-graceum is annual herb, Gupta (2010). Habit of Melilotus was annual or biennial herbs, sparse to glabrescent. Stems erect, terete, stipules falcate, entire. Leaves trifoliate; petiole slender, usually Leaflets obovate, margins shallowly serrated And important family Papilionaceac were eaten as vegetable as in Phaseolus vulgaris and Cajanus cajan, Dolichos lablab and Cyamopsis tetragonoloba ,Trigonella Foenum-graecum, Vigna sinensis and used as fodder as in Cyamopsis tetragonoloba ,Melilotus indica, Medicago sativa, Trifolium alexandrinum and Trifolium resupinatum and used oil for cooking and. Pandey 2004.

Stomata were anomocytic and the guard cells were surrounded by 3,4 or rarely 5 subsidiary cells. They were found on both surfaces, but the upper Epidermis had fewer stomata Özbek et al. (2014). Aanomocytic stomata in Phaseolus vulgaris bears anisocytic stomata, Erythrina indica, Phaseolus mungo, lineate bears only paracytic stomata. Melilotus alba, Melilotus indica, bear both anisocytic and anomocytic stomata. Leaf of Erythrina is -blade, in front view, epidermis with predominance of branched and glandular trichomes and paracytic and anisocytic stomata on both surfaces. In the adaxial surface, epidermal cells on the veins had prismatic crystals on their interior. The anticlinal walls of epidermal cells are sinuous on both surfaces leafblade presented branched trichomes with uniseriate stems Tripathi and Mondal (2012)
Leaf of Erythrina is -blade, in front view, epidermis with predominance of branched and glandular trichomes and paracytic and anisocytic stomata on both surfaces. In the adaxial surface, epidermal cells on the veins had prismatic crystals on their interior. The anticlinal walls of epidermal cells are sinuous on both surfaces leaf-blade presented branched trichomes with uniseriate stems Márcia $\boldsymbol{e t}$ al.(2013).

Iflorescence of Melilotus is racemes white with bluish-purple tipped wings and keel, 3-6 mm. Ovary narrowly ovate with two ovules. Legume ovoid, 3-5 $\mathrm{mm}$, puberulent, with longitudinal ridges. The seedsurface ornamentation was smooth in $M$. albus, papillatein $M$. sulcatus, granulate in M. elegansand striate in $M$. indicus. The hilum was elliptic. The seed coat ornamentation was tuberculate-rugose. Seeds 2, dark brown to dark green in color, globose to obovoid, papillate. The pollen grains of M. bicolor were $98 \%$ trizono colporate, $2 \%$ syncolporate and were isopolar and radially symmetrical. Their shape was subprolate. The colpi was long and narrow with clear margins. Pores are elongate or circular. The aperture membrane was granulate. The pollen in $M$. indicus is tricolporate, subprolate-prolate and the sculpture was micro reticulate. Pollen grains in $M$. albus, M. sulcatus, M. siculus Begum et al. (2014). Pollen grains of Coronilla scorpiodes are colporate and striate-rugulate ornamentation Diez and Ferguson (1996). Pollen grains of Papilionoideae are in monads Takhtajan (2009). Pollen grains of Ebenus had tricolpate apertures, circular in polar view, with shallow colpi, and lumina of the reticulum sharply Ghanavatiet et al. (2011).

The present study occur on 19 genera with 37 species are trifoliate plants belonging to the subfamily Faboideae (Papilionoideae).The investigations including stems, leaves, flowers, fruits, and seeds the characters of these organs recorded comparatively for each species. 


\section{Aim of the work}

This study aims to clear the inter relationships of between these studied samples, by using a numerical analysis program to reach to this purpose.

\section{Materials and Methods}

\section{Materials:}

This work was carried out in the Department of Agricultural Botany, Faculty of Agriculture, Al-
Azhar University, Nasr city, Cairo, Egypt. The plant samples were obtained from eight different locations as shown in (Table1). The plant contained 37 species, representing 19 genera belonging to the subfamiliy Faboideae, all with trifoliate leaves. The identification of the collected plants were achieved by comparing their morphological characters with those of the previously identificated plants as published by Täckholm (1974) and Boulos (1999)

Table 1. Alphabetical list of (37) species, representing (19) genera belong to subfamiliy Faboideae. The studied samples were obtained from eight Egyptian places from various locations. These locations are: C. = Cairo university herbarium; I.= Ismaalia Governerate; N.= Nasr city Cairo; Q.= Qalubia Governerate; R.= Orman Garden (Giza); and S.= Areysh North Sainai .

\begin{tabular}{|c|c|c|}
\hline No. & Species & Source \\
\hline 1 & Argyrolobium abyssinicum Jaub. \& Spach. & $\mathbf{C}$ \\
\hline 2 & Cajanus cajan (L.) Millsp. & $\mathbf{N}$ \\
\hline 3 & Coronilla scorpiodes (L.)W.D. J. Koch. & $\mathbf{C}$ \\
\hline 4 & Cyamopsis tetragonoloba (L.) Taub. & $\mathbf{N}$ \\
\hline 5 & Dolichos lablab L. & $\mathbf{R}$ \\
\hline 6 & Ebenus armitagei Schweinf .\& Taub. & $\mathbf{C}$ \\
\hline 7 & Erythrina caffra Thunb. & $\mathbf{G}$ \\
\hline 8 & E. corallodendron $\mathrm{L}$. & $\mathbf{R}$ \\
\hline 9 & Glycine $\max (\mathrm{L}$.$) Merr.$ & $\mathbf{I}$ \\
\hline 10 & Medicago arabica (L.) Huds. & $\mathbf{C}$ \\
\hline 11 & M. constricta (Durieu) Ponert & $\mathbf{C}$ \\
\hline 12 & M. intertexta (L.) Miller & $\mathbf{C}$ \\
\hline 13 & M. littoralis Rohde ex.Lois. & $\mathbf{C}$ \\
\hline 14 & M. minima (L.) Bart & $\mathbf{C}$ \\
\hline 15 & M. orbicularis (L.) Bartal & $\mathbf{S}$ \\
\hline 16 & M. polymorpha L. & $\mathbf{C}$ \\
\hline 17 & M. sativa $\mathrm{L}$. & $\mathbf{Q}$ \\
\hline 18 & Melilotus elegans Salzm ex.Ser. & $\mathbf{S}$ \\
\hline 19 & M. indica (L.) All. & $\mathbf{I}$ \\
\hline 20 & M. siculus (Turra)B.D.Jacks & $\mathbf{S}$ \\
\hline 21 & M.sulcatus Desf. & $\mathbf{S}$ \\
\hline 22 & Onomis serrate Forssk & $\mathbf{M}$ \\
\hline 23 & O. vaginalis M.Vahl. & $\mathbf{M}$ \\
\hline 24 & Phaseolus vulgaris L. & $\mathbf{Q}$ \\
\hline 25 & Pseudarthia hookeri Wight\& Arn & $\mathbf{N}$ \\
\hline 26 & Psoralea plicata Delile & $\mathbf{N}$ \\
\hline 27 & Rhynchosia minima (L.) DC. & $\mathbf{N}$ \\
\hline 28 & Tetragonolobus purpureus L. & $\mathbf{N}$ \\
\hline 29 & Trifolium alexandrinum L. & $\mathbf{Q}$ \\
\hline 30 & T. respinatum $\mathrm{L}$. & $\mathbf{C}$ \\
\hline 31 & T.stellatum L. & $\mathbf{C}$ \\
\hline 32 & Trigonella arabica Delile & $\mathbf{C}$ \\
\hline 33 & T. hamosa L. & $\mathbf{C}$ \\
\hline 34 & T. foenum-graecum L. & $\mathbf{C}$ \\
\hline 35 & T.maritime Poir. & $\mathbf{C}$ \\
\hline 36 & T. monspelica L. & $\mathbf{C}$ \\
\hline 37 & Vigna sinensis L. & $\mathbf{I}$ \\
\hline
\end{tabular}

\section{Methods:}

Parts of fresh materials were fixed in F.A.A. solution for a minimum period of 48 hours and then samples were taken from various parts of plant organs to study different aspects. The dry specimens parts were resuscitated by boiling with a few drops of 
the detergent "misrol" then treated as fresh materials. Epidermal peels of mature foliage leaves and stems were cleared in warm lactic acid, then they were examined microscopically to study the structure of mature stomata, types of trichomes, cell walls shaped and cell surface ornamentations .

The floral parts were dissected under stereomicroscope into their different parts and spread over slides. The sample parts were cleared by worming in lactic acid to study the macro- and micro- morphological features of the floral parts. Semi-permanent pollen preparations were made according to the method of Franks and Watson (1963) . Pollen dimensions have been measured using a calibrated ocular micrometer.

\section{Results and Discussions}

Morphological aspects have been recorded for stem, leaves, flowers, fruits and seeds for 37 species belonging to Faboideae. They consist of 83 characteristic covering both the vegetative and floral organs. These characteristics are described in details as follows:

Habit : The plants are mostly annual herbs as in Phaseolus vulgaris and Glycine max (Fig. 1) but they are perennial shrubs as in Psoralea plicata and Cajanus cajan (Fig. 2) or perennial trees as in Erythrina spp. (Fig. 3). All the studied Medicago species are annual herbs except Medicago sativa which has perennial herbs. This is in harmony with Meikle (1985) and Gupta (2010).

Stem : It is usually erect except some studied samples such as Dolichos lablab Medicago constricta Vigna sinensis (Fig. 4) which has climbing stems and Medicago littolaris (Fig. 5) which has prostrate stems. The stem is mostly angular, herbaceous and hollow as in Medicago spp. and Melilotus spp. , while some plant samples have cylindrical woody and solid stems specially in shrubs and trees samples. Most examined samples with hairy stems such as Vigna sinensis, in few samples stem is smooth such as Medicago constricta, while rough stem observed only in Erythrina spp.

Leaf: It is usually petiolate and stipulate as in Cajanus cajan (Fig. 6) except Coronilla scorpiodes which has sessile leaf (Fig. 7). Stipules are mostly leafy as in Cajanus cajan, while they are small appendages in few species such as Dolichos lablab. The leaflets are varies in shapes, they are ovate as in Erythrina corallodendron (Fig. 8), cordate as in Dolichos lablab (Fig. 9), lanceolate as in Cajanus cajan (Fig. 10), oblong as in Melilotus sulcatus (Fig. 11), obcordate as in Medicago littoralis and obovate as in Medicago orbicularis (Fig. 12). The apex of lamina is notched as in Medicago littoralis, acute as in Cajanus cajan, acuminate in Dolichos lablab and rounded as in Melilotus elegans (Figs. 12, 13, 14 and 15). The base of lamina is rounded as in Erythrina corallodendron, cuneate as in Medicago orbicularis and cordate as in Dolichos lablab (Figs. 16, 17 and 18). The leaf margin is entire in Melilotus sulcatus, serrate in Medicago littoralis and wavy in Psoralea plicata (Figs. 19, 20 and 21 respectively) these results are in agreement with the finding of Özbek et al. (2014).

The micromorphological studies on the leaflet epidermis showed:

a- Hairs: Several epidermal hair forms are recorded on the stem and leaflets adaxial and abaxial surfaces and also on the floral parts of the studied samples. These forms are distinguished into : Shaggy hairs with acute apex as in Trifolium respinatum (Fig. 22.), unicellular hairs unbranched with acute apex as in Medicago sativa (Fig. 23), unicellular hairs with glandular apex Erythrina caffra (Fig. 24), unicellular hairs branched with eglandular hair as in Cymopsis tetragonolobus (Fig. 25), multicellular hair branched with rounded apex as in Melilotus elegans (Fig. 26) and multicellular hair branched with glandular apex as in Dolichos lablab (Fig. 27).

b-The epidermal cell walls in surface view are mostly wavy or sinuate as in Argyrolobium abyssinicum (Fig. 28), but some investigated species have epidermis with straight cell walls as in Coronilla scorpiodes (Fig. 29), calcium oxalate crystals are observed in the epidermis in most examined sample as in Melilotus sulcatus, (Fig. 30). These observation are in accordance with Tripathi and Mondal (2012).

c- Stomata : Five types of stomata are recorded the studied taxa these types are anisocytic as in Trigonilla monspeliaca (Fig.31), tricytic as in Vigna sinensis (Fig.32), paracytic as in Glycine max (Fig.33), tetracytic as in Erythrina caffra(Fig.34) and anomocytic as in Trigonella maritime (Fig.35), the common types of stomata are anisocytic and paracytic. Both associated and abnormal stomata are observed in few studied samples such as Melilotus salcata, Melilotus indica and Ononis vaginalis (Figs. 36, 37 and 38 respectively) These observations are in accordance with Márcia et al.(2013). .

Flowers: all the investigated samples have the flowers in clusters or inflorescences, they are in racemes as in Melilotus elegans (Fig. 39), capitate as in Trifolium alexandrinum (Fig. 40), umbel in Erythrina caffra (Fig. 41), head in Trigonilla maritima (Fig. 42) and spike as in Pseudarthia hookeri.

Calyx: Calyx is usually with five united sepals in most examined samples as in Dolichos lablab, but few samples contain only four sepals as in Cajanus cajan.

Sepals may be equal in length as in Dolichos lablab (Fig . 43) or unequal as in Glycine max (Fig .44) Calyx is persistant in most of the examined species as in Melilotus spp. but it deciduous calyx recorded in few species as in Medicago polymorpha. 
Sepals are often possess different shape of hairs , these hairs are unicellular or multicellular also they are glandular or eglandular. Average of sepals length of ranged between $0.3 \mathrm{~mm} .-1.7 \mathrm{~cm}$. while Average width are $0.3 \mathrm{~mm} .-1.7 \mathrm{~cm}$. and number of veins per sepals varies from one to four.

Corolla: is usually polypetalous, it consists of 5 free petals with papilionate shape. The apex of standard is retuse in some plant samples as in Argyrolobium abysinicum, while they are obtuseacute in Cymopsis tetragonolobus, and Medicago constricta. Standared is clawed in all examined samples, but not clawed in Erythrina corallodendron. This petal is mostly have dark veins, while in Medicago constricta and M. littoralis the color of blade as same as veins. Standered is glabrous in most of samples as in Coronilla scorpiodes but it is hairy in few samples as in Argyrolobium abyssinicum. Lateral petals were known as wings, the anterior pairs of united petals is termed keel this encloses two united petals contains both stamens and carples . keel is clawed in most samples while it is not clawed in few samples as Phaseolus vulgaris, keel with dark veins in all exmined samples except in Medicago constricta, $M$. littoralis which have veins as same as blade. Average of petal length is. $0.2 \mathrm{~mm} .-5 \mathrm{~cm}$. Average of petals width is $0.2 \mathrm{~mm} .-2.7 \mathrm{~cm}$. Number of veins are ranged between 4 and 28. Petals color varies from white as in Trigonilla arabica, yellow as in Cajanus cajan, Trigonilla maritima, red as in Erythrina corallodendron, rose in Ebenus armitagei orang in Erythrina caffra or move in Dolichos lablab and Medicago sativa.

Androecium: stamens are united in all examined taxa, except in Dolichos lablab which have free stemens, the united stamens are mostly diadelphus as in Glycine max, Phaseolus vulgaris, and Trigonilla hamosa (Fig. 45), but some samples have monadelphus stamens such as Coronilla scorpiodes, (Fig. 46) Anther is mostly with elongate shape as in Cajanus cajan, while it is globular in some examined taxa as in Medicago arabica. The staminal filament is usually included in corolla in most examined samples, but it is excluded from corolla in the others as in Trigonella arabica and Melilotus indica. The staminal filament is often glabrous, while it is hairy in few species. The filament length varies from $2 \mathrm{~mm}$. to $3.1 \mathrm{~cm}$. in most examined samples.

Pollen grains: The pollen grains are usually monads and globular to oblong in all examined plants, these grains have three apertures they may be 3-porate as in Coronilla scorpiodes (Fig. 47), 3colpate as in Medicago polymorpha (Fig.48) or 3 colporate as in Medicago minima (Fig.49), Exine texture is mostly granulose in most examined species except some species which have reticulate or smooth exine. The equatorial dimensions of pollen grains ranged between 12 and $56 \mu$. in all examined plants. These results are in agreement with Diez and Ferguson (1996). Takhtajan (2009). Ghanavatiet et al. (2011). Begum et al. (2014).

Gynoecium: ovary is hairy in most examined plants as in Cymopsis tetragonoloba, while it is glabrous in some sampless as in Tetragonolobus purpureus. Style is hairy in few plants as in Coronilla scorpiodes and Erythrina, while it is glabrous in most of samples as in Medicago spp. and Trigonella spp.. Stigma with glandular hairs in Erythrina caffra, Glycine max, Medicago polymorpha and Phaseolus vulgaris, but it eglandular hairs as in Psoralea plicata, Trifolium stellatum and Vigna sinensis.

Fruits: is pod or legume. Pod is flattened in most examined samples as in Dolichos lablab (Fig. 50) while it is terete in some plants as in Erythrina caffra (Fig. 51). The beak of pod is present in most examined plants as in Erythrina caffra (Fig. 51), but it is absent in the others as in Onomis serrate. The pod constricted between seeds in few plants as in Erythrina caffra (Fig. 51). The shapes of fruits are straight as in Dolichos lablab (Fig. 50), (Fig), curved in Trigonilla hamosa (Fig. 53) and spirraly in Medicag intertexta, (Fig. 52). The fruit exocarp is woody in Erythrina caffra (Fig. 51) herbaceous in Medicago intertexta, (Fig. 52) or papary in Trigonilla hamosa (Fig 53), leathery as in Dolichos lablab (Fig. 50). Fruit apex are varies in shapes it is rounded in few plants as in Medicago littoralis, acute or acuminate in most examined plants as in Trigonella maritime. Fruits are smooth in few samples as in Erythrina caffra, hairy in Glycin max (Fig. 54), spiny in Medicago constricta (Fig. 55). The average length of fruit is $2,2 \mathrm{~cm} .-14.5 \mathrm{~mm}$., while the average width of is $0.2 \mathrm{~mm} .-2.5 \mathrm{~cm}$.

Seeds: seed surface is usually smooth as in Coronilla scorpiodes but few samples have corrugated -grooved seeds as in Ononis vaginalis. Seeds are usually have hilum as in Vigna sinensis while some species their seeds without hilum as in Ebenus armitagei .

Seeds arranged in pod in one row in all studied samples except Onomis serrate the seeds arranged inside the pod into two rows. Seeds shapes varies from globular as in Cymopsis tetragonolobus, oblong in Phaseolus vulgaris (Fig. 57), kidney in Medicago intertexta (Fig. 56), obovate Trigonilla arabica (Fig. 58), ovate as in Trifolium alexandrinum. Seeds are also varies in color it is yellow in Argyrolobium abyssinicum, brown in Medicago intertexta, black in Rhynchosia minima, cream in Vigna sinensis orange in Erythrina corallodendron. Seeds length ranged between .0 .2 mm.-1.5 cm., while the width ranged between $0.1 \mathrm{~mm}$. $-0.7 \mathrm{~mm}$. Number of seeds per pod varies from 1 to 23 seeds. 
Table 2: List of the 83 different characters, recorded comparatively based on the morphological features of 37species(19 genera) representing trifoliate plants (Fabaceae). These characters are distinguished into 47 qualitative; 17 multistate and 19 numerical characters.

\section{Vegetative characters:}

\section{Qualitative characters:}

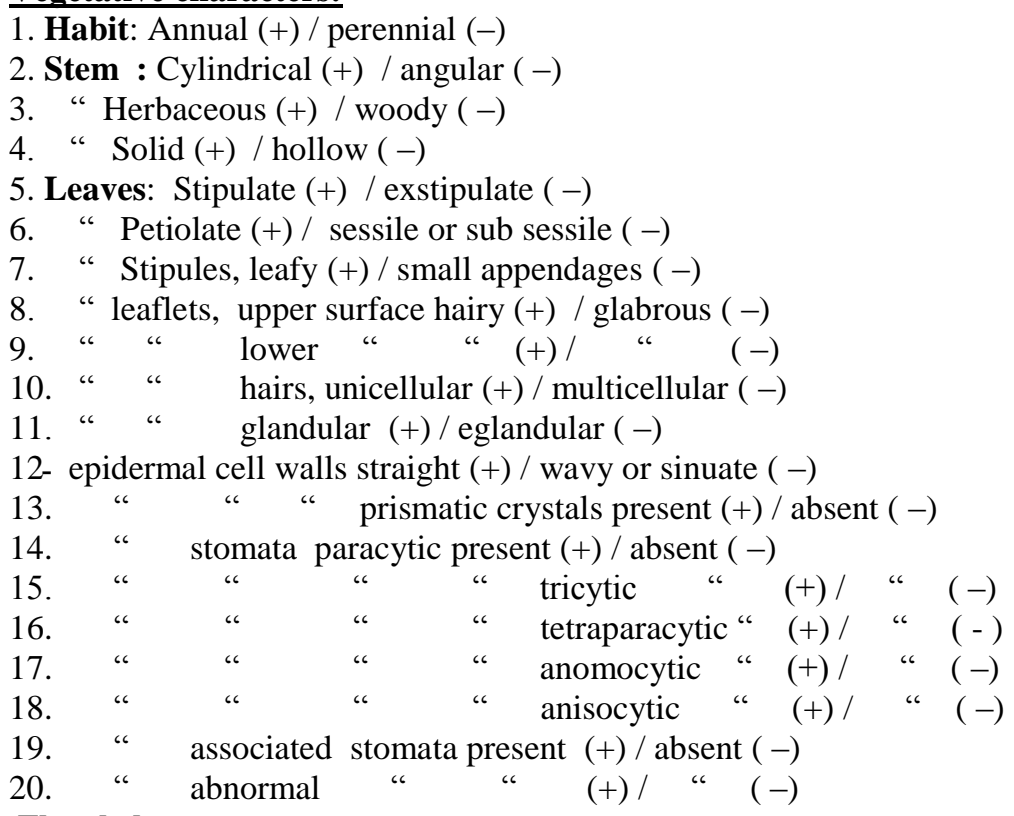

Floral characters :

21. Calyx, sepals, five (+) / four (-)

22. “ equal in length $(+) /$ unequal $(-)$

23. “ persistent $(+) /$ deciduous $(-)$

24. " hairy $(+) /$ glabrous (-)

25. Corolla, hairy $(+) /$ glabrous -

26. " " standard, apex retuse (+) / obtuse-acute (-)

27. " clawed (+)/ not clawed

28. " " with dark veins $(+) / \operatorname{not}$ so $(-)$

29. “ " wings clawed (+) / not clawed ( - )

30. “ " with dark veins $(+) /$ not so $(-)$

31. " " margin entire $(+) / \operatorname{not}$ so $(-)$

32. “ keel clawed $(+) / \operatorname{not}$ clawed $(-)$

33. " with dark veins $(+) /$ not so-

34. Androecium, stamens, united (+) / free (-)

35. " " -monodelphus $(+) /$ diadelphus $(-) /$ if free *

36. " " anther, elongate $(+) /$ globular $(-)$

37. “- filament, inserted in corolla $(+) /$ exerted from corolla $(-)$

38. “ " hairy (+) / glabrous ( -$)$

39. Gynoecium, ovary , hairy (+) / glabrous ( -)

40. " "style, hairy (+) / glabrous ( - )

41- stigma, glandular $(+) /$ eglandular $(-)$

42. Fruits, pod, terete $(+) /$ flatted $(-)$

43. " " " with beak $(+) /$ not so $(-)$

44. " " " constricted between seeds $(+) /$ not so $(-)$

45. " " " " seeds arrangement in one row $(+) /$ in two rows $(-)$

46. " " " " surface smooth $(+) /$ corrugated or grooved ( -$)$

47. “ seed with hilum (+) / without hilum (-)

\section{Multistate character}

48. Habit: (3 categories): herbs 1; shrubs 2 and trees 3 .

49. Stem: (3 categories): erect 1; climbing 2 and prostrate 3 .

50. " touch: (3 categories): glabrous 1 ; hairy 2 and rough 3 .

51. Leaflet, apex; (4 categories): acute 1, acuminate 2, rounded 3 and notched 4 .

52. “ base; ( 3 categories): rounded 1 , cuneate 2 , and cordate 3 . 
53. " margin: (3 categories): entire 1; serrate 2and wavy 3.

54. “ blade shapes: (5 categories): ovate 1, cordate 2, lanceolate 3 , oblong 4, and obovate 5 .

55. Inflorescence : (5 categories): raceme 1; capitate 2; umbel 3; head 4 and spike 5.

56. Corolla color: ( 6 categories): white 1; yellow 2; red 3; rose 4; orange 5 and move 6 .

57. Pollen grain aperatures :( 3 categories): porate 1 ; colpate 2 and colporate 3.

58. “ " exine sculpture: ( 3 categories): smooth 1; granulose 2 and reticulate 3. 59. Fruits straightness: ( 4 categories): straight 1 ; curved 2; heliocoide 3 and spiraly 4 .

60. “ exocarp: ( 4 categories): woody 1; herbaceous 2, lathery 3 and papry 4.

61. “ apex:( 3 categories): rounded 1; acute 2 and acuminate 3 .

62. " touch ( 3 categories): smooth 1 ; hairy 2 and spiny 3 .

63. Seed shapes: ( 5 categories): globular 1; oblong 2; kidney 3 , obovate 4 and ovate 5 .

64. “ colors: ( 6 categories): yellow 1; brown 2; black 3; white 4; cream 5 and orange 6 .

III. Numerical characters

65. Average of leaf length in $\mathrm{cm}$.

66. " " " width

67. “ " " " leaflet length

68. " " " " width

69. Average of sepals length in $\mathrm{cm}$.

70. " " " " width "

71. “ “ “ “ " “ number of sepal veins.

72. Average of petal length in $\mathrm{cm}$,

73. " " " petal width "

74. “ " " veins per petal.

75. " stamen length in $\mathrm{cm}$.

76. “ " pollen grains polar dimension $(\mathrm{P})$ in $\mathrm{u}$.

77. " " " " equatorial dimension $(\mathrm{E})$ in $\mathrm{u}$.

78 “ $\mathrm{P} / \mathrm{E}$

79. “ fruit pod length in $\mathrm{cm}$.

80. " width “

81. seed length “ "

82. seed width “

83. Number of seed per pod. 
Table 3. Data - matrix of 83 different characters, recorded comparatively for 37 species (19 genera) representing the trifoliate plants belonging to Faboideae. The recorded characters based on the vegetative, floral and fruit features. These characters are distinguished into 47 qualitative; 17 multistate and 19 numerical characters.

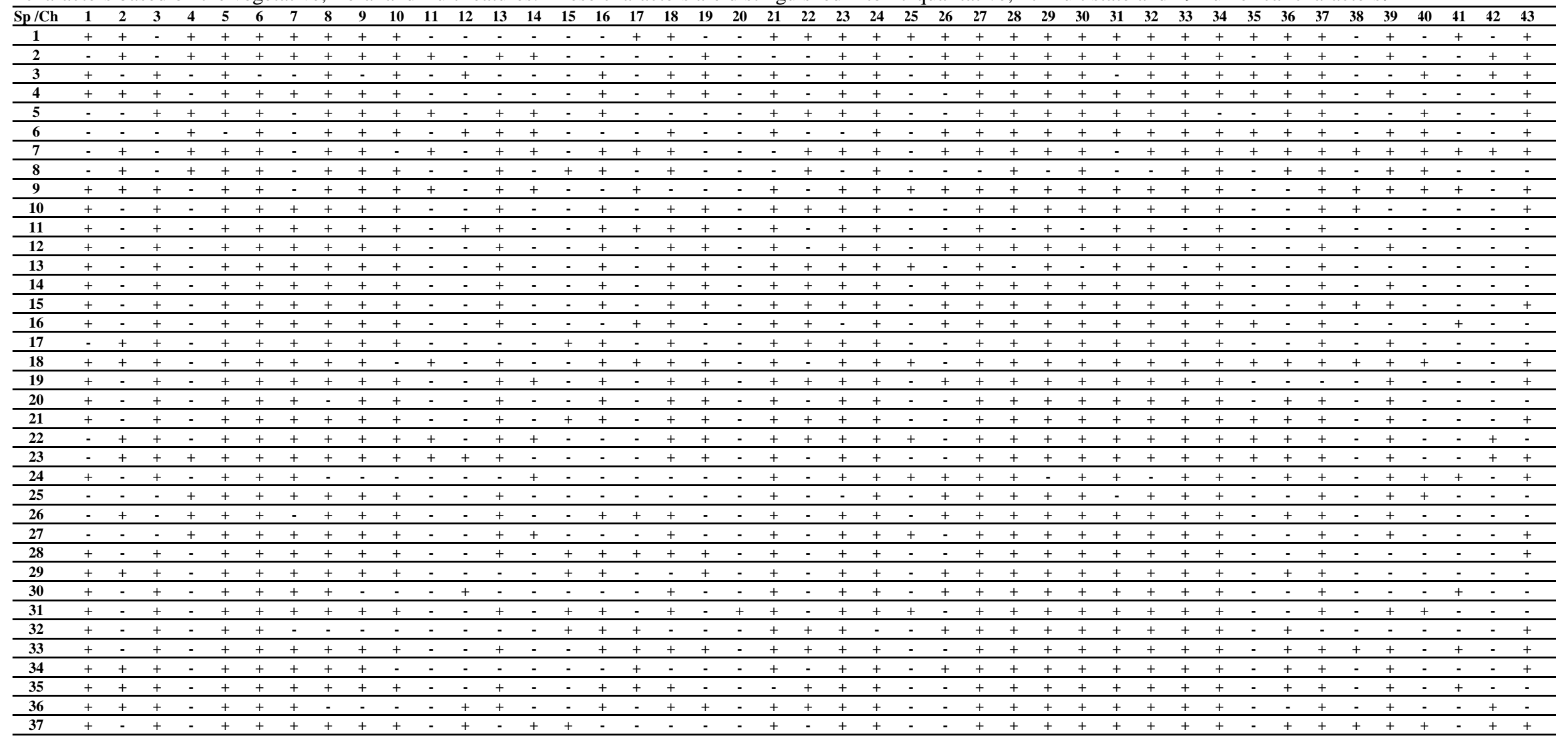


Table 3: cont.

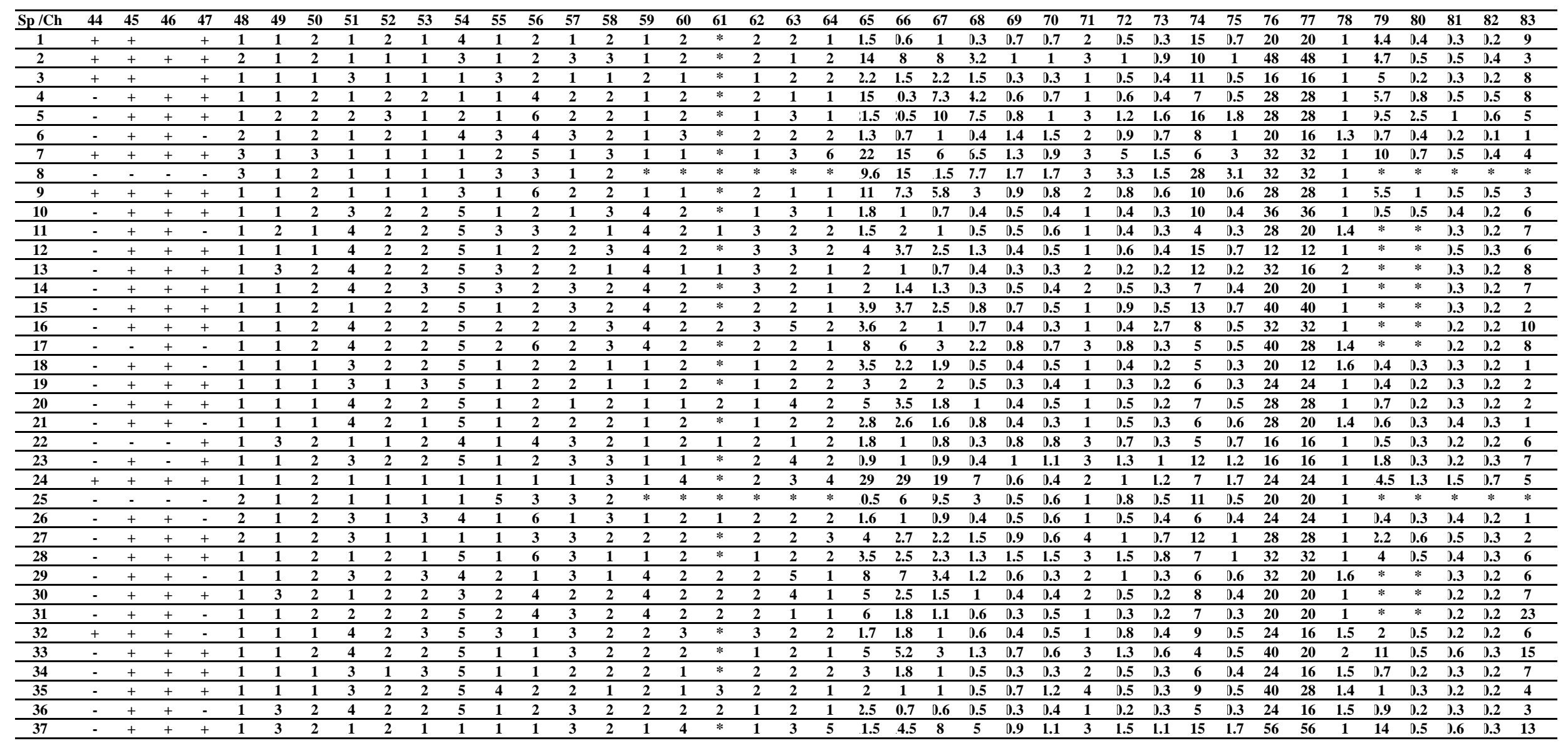



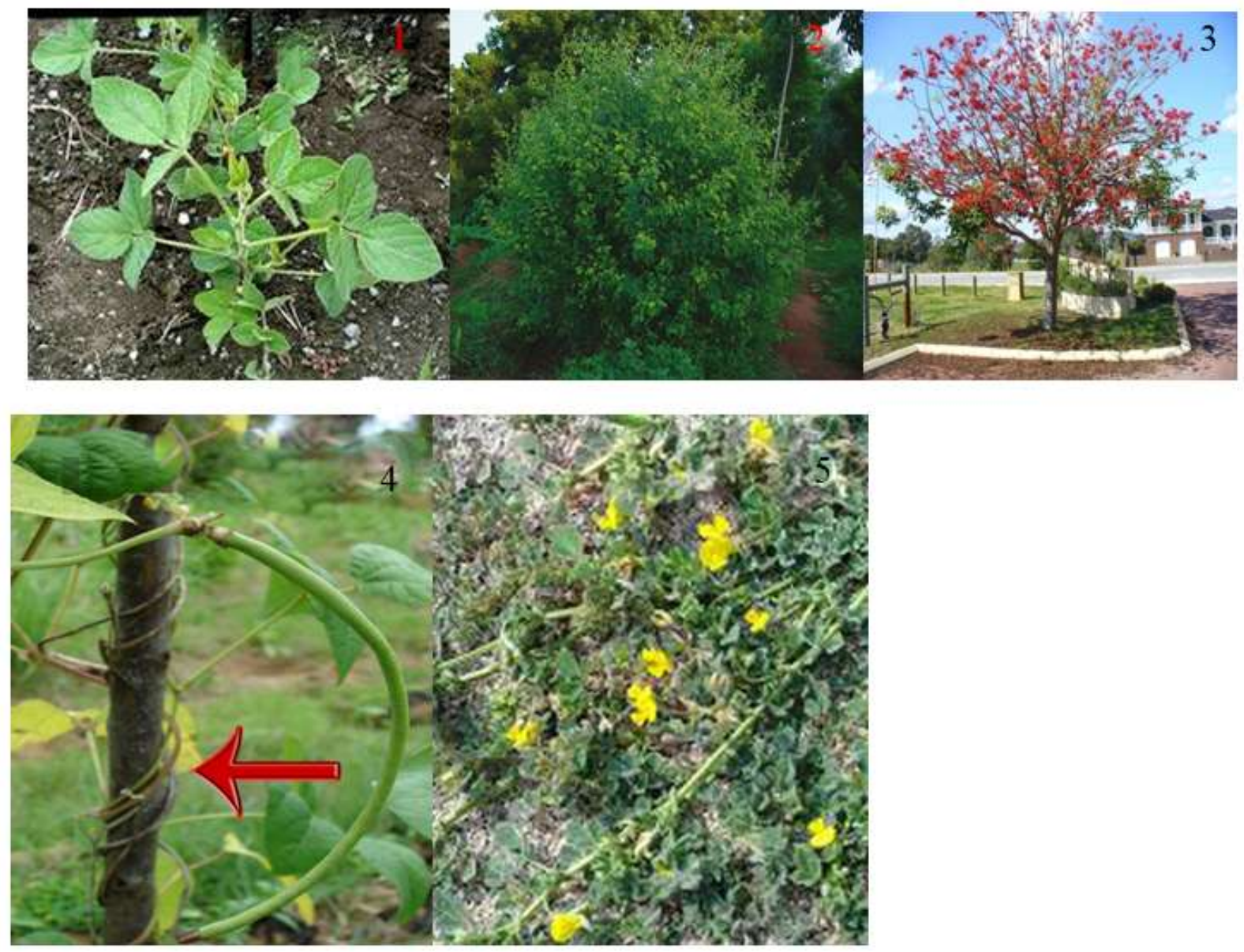

Figures: (1 - 5) Showed types of habit and stem of : Fig. (1) Glycine max, Fig; (2) Cajanus cajan; Fig. (3) Erythrina caffra; , Fig. (4) Vigna sinensis and Fig. (5) Medicago littolaris 


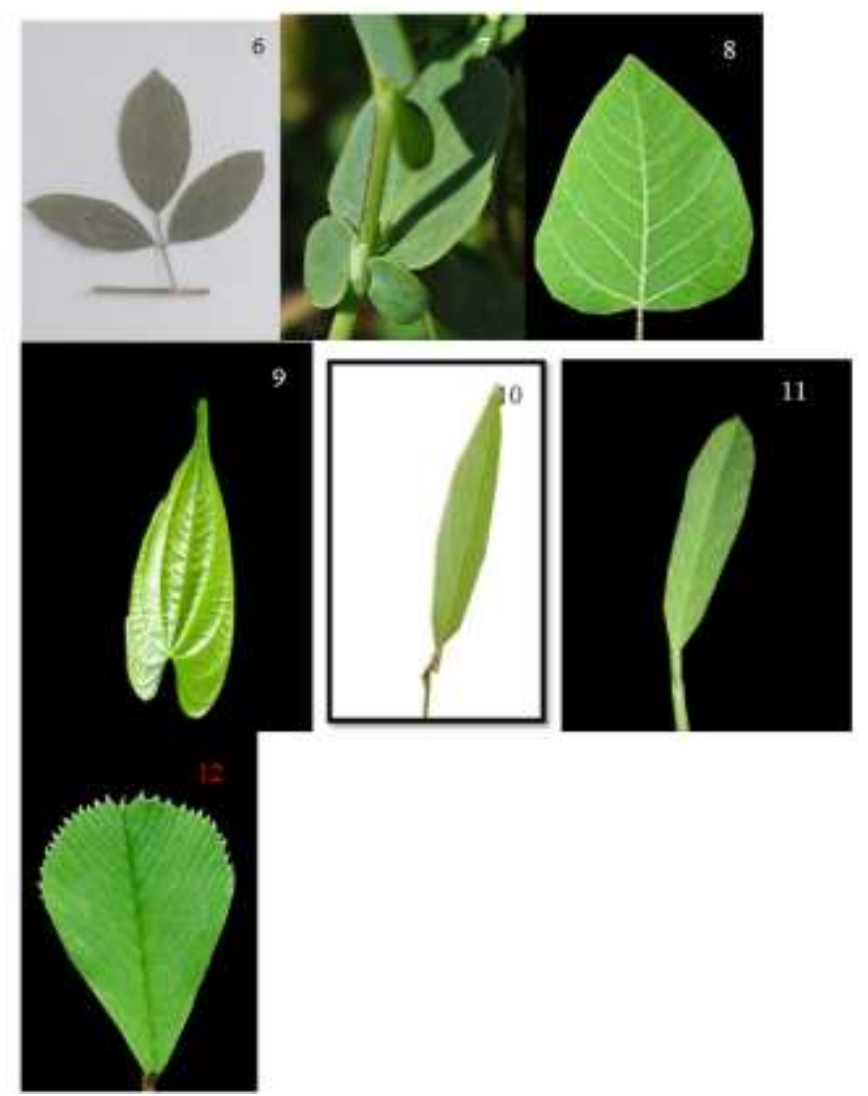

Figures : $(6-12)$ Showed leaflet shapes :

Fig. (6) Cajanus cajan; Fig. (7) Coronilla scorpiodes ; Fig. (8) Erythrina corallodendron,, Fig. (9) Dolichos lablab, Fig. (10) Cajanus cajan, Fig. (11) Melilotus sulcatus Fig. and (12) Medicago orbicularis.

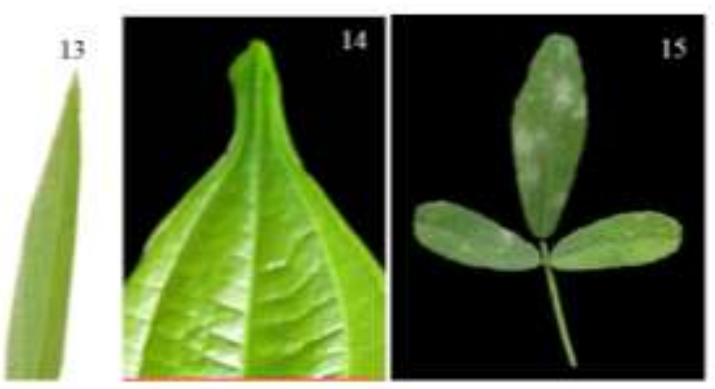

Figures : (13 - 15) Showed leaflet laminal apex shapes of:

Fig. (13) Cajanus cajan, Fig. (14) Dolichos lablab, Fig. and (15) Melilotus elegans Fig.

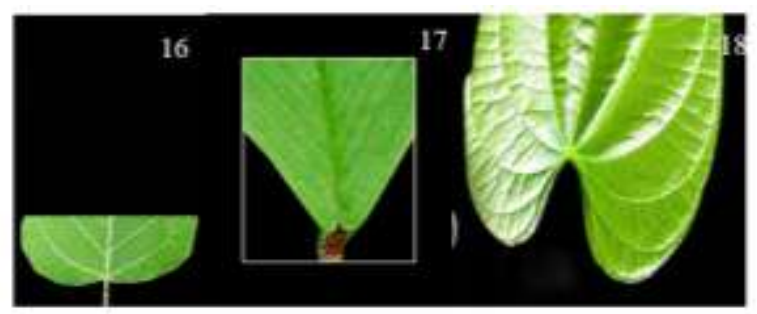

Figures : (16-18) Showed leaflets laminal base shapes of:

Fig. (16) Erythrina corallodendron, Fig. (17) Medicago orbicularis and Fig. (18) Dolichos lablab 

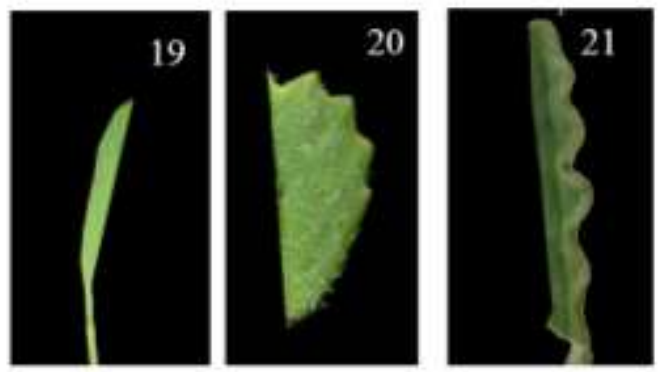

Figures : (19-21) Showed leaflets laminal margin shapes of: Fig. (19)Melilotus salcatus, Fig. (20) Medicago littoralis and Fig. (21) Psoralea plicata.

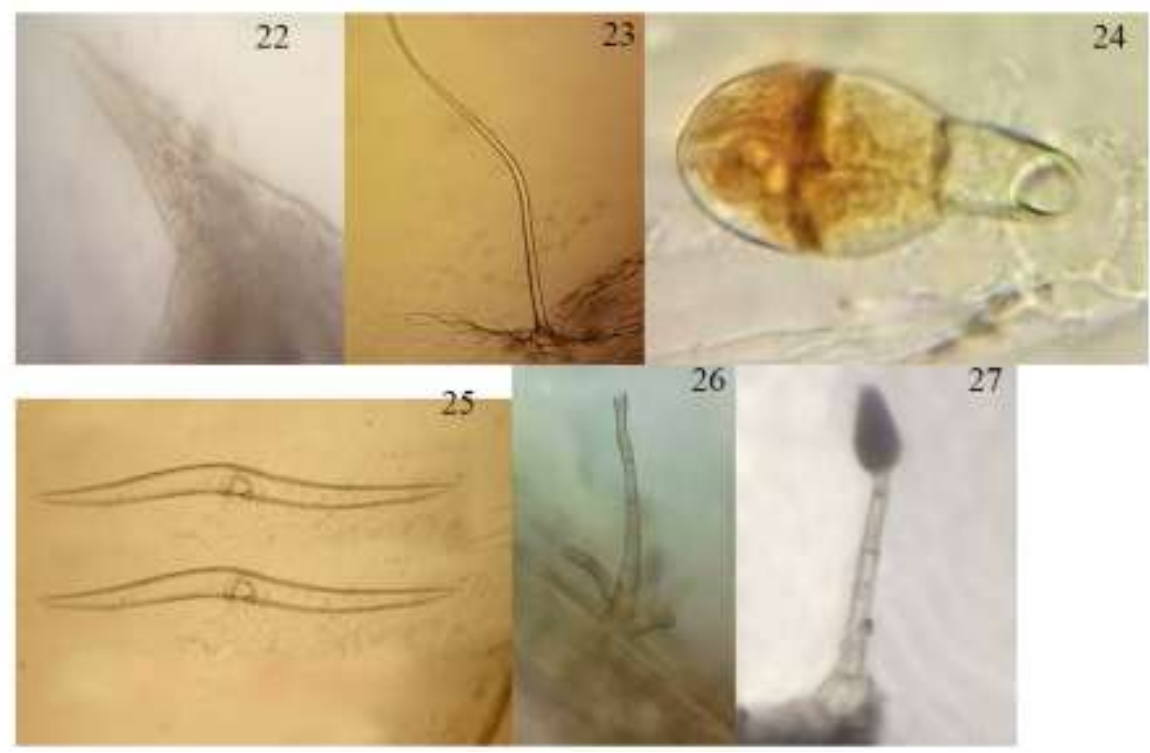

Figures: (22-27) Showed hair forms on the leaflets: Fig. (22)Trifolium resupinatum, Fig. (23) Medicago sativa ,Fig. (24) Erythrina caffra Fig .(25)Cymopsis tetragonolobus, Fig.(26) Melilotus elegans and Fig(27) Dolichos lablab.

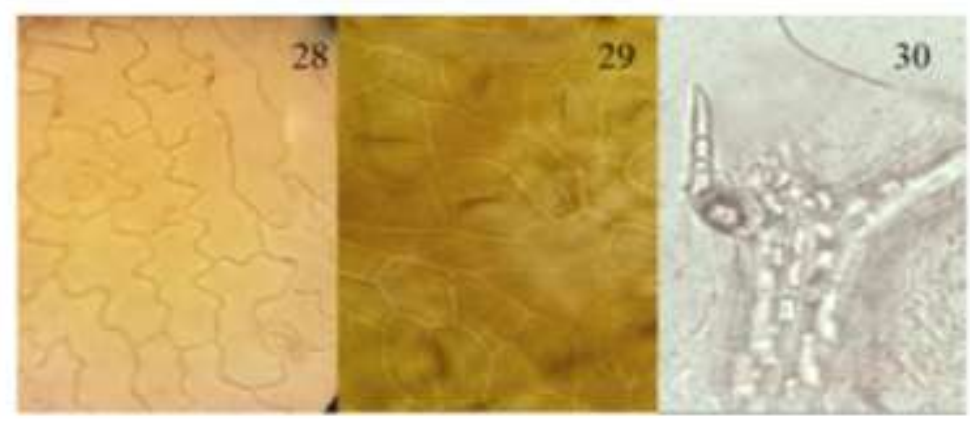

Figures : (28 - 30) Showed The epidermal cell walls and Calcium oxalate crystals,Fig. (28)Argyrolobium abyssinicum, Fig. (29) Coronilla scorpiode and Fig. (30) Melilotus sulcata. 


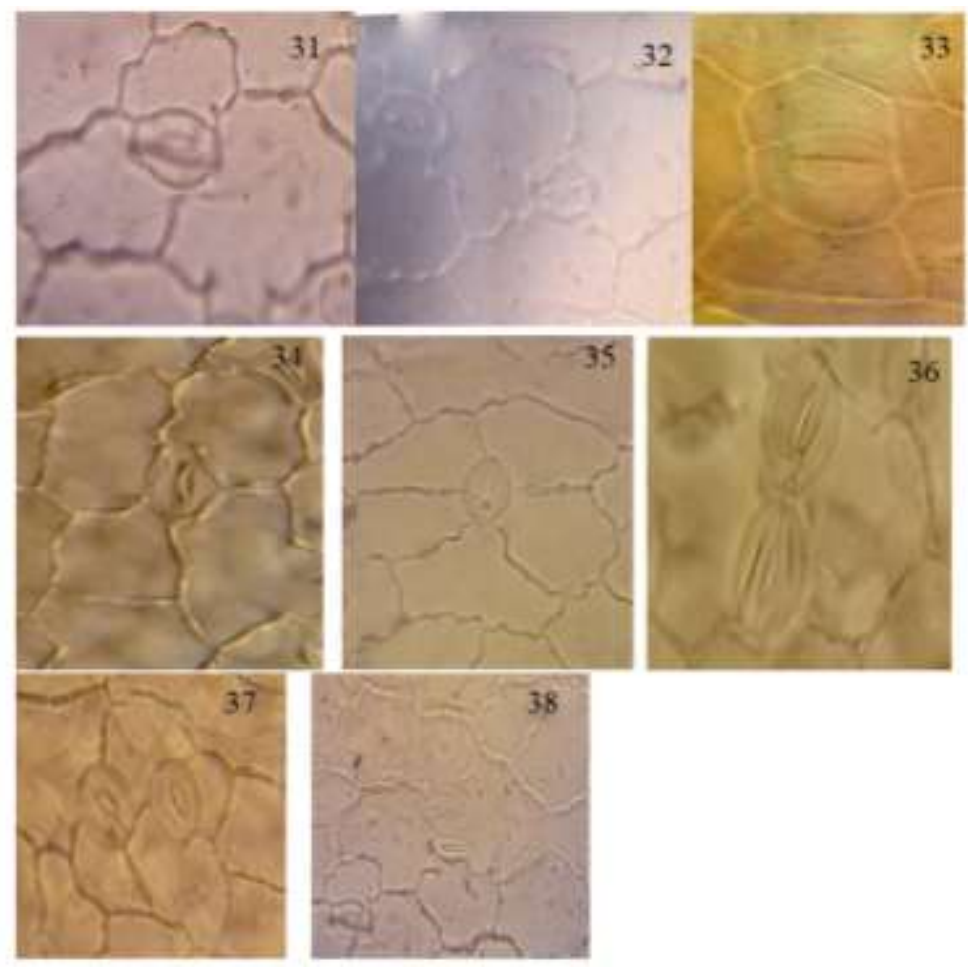

Figures : (31 - 38) Showed stomatal types, associated and abnormal stomata ,Fig. (31)Trigoella monspeliaca, Fig. (32) Vigna sinensis ,Fig. (33) Glycine max, Fig.(34) Erythrina caffra, Fig.(35) Trigoella maritime, Fig.(36) Melilotus sulcata ,Fig.(37) Melilotus indica and Fig.(38) Ononis vaginalis.
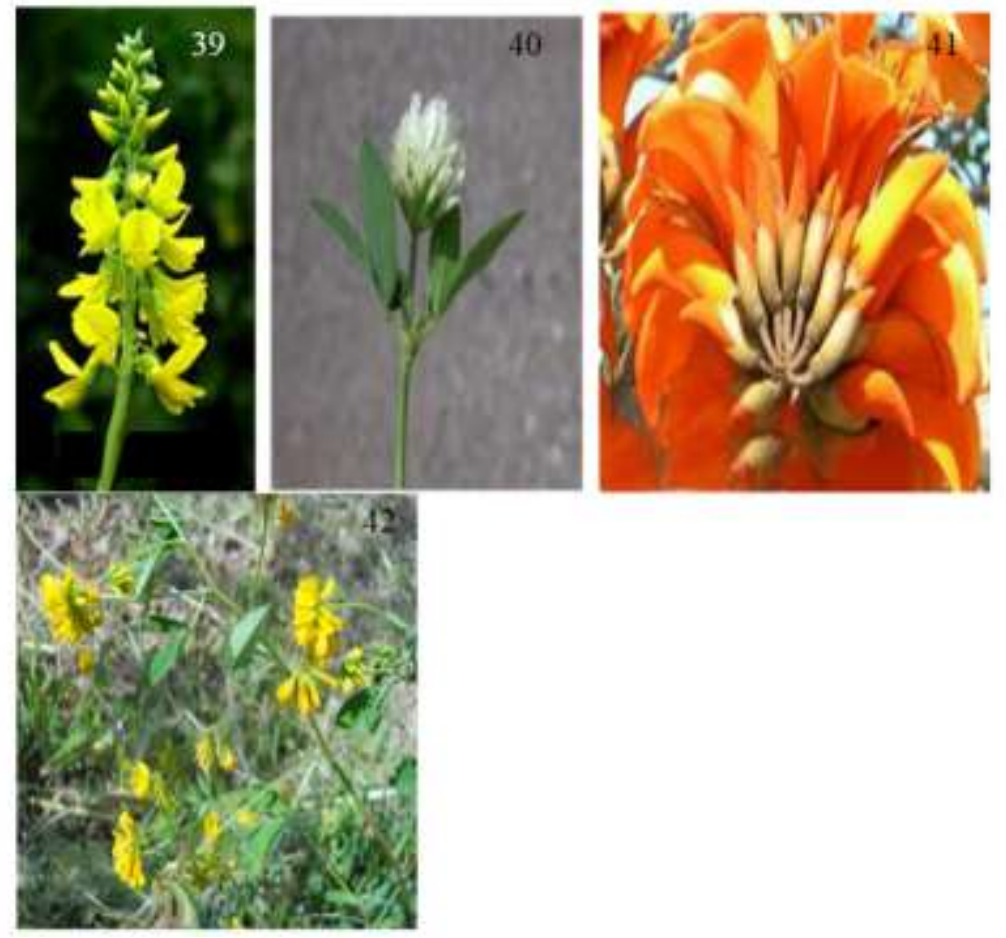

Figures : (39-42) Showed inflorescence types of, Fig.(39) Melilotus elegans, Fig.(40)Trifolium alexandrinum Fig.(41) Erythrina caffra and Fig.(42) Trigonella maritime. 

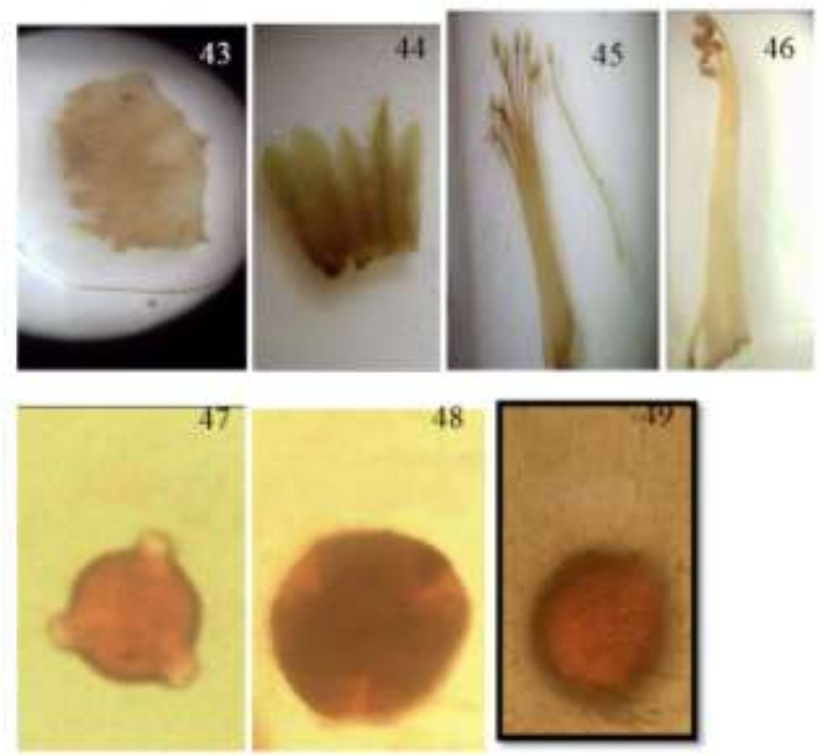

Figures : (43-49) Showed equals and unequals sepals; monadelphus and diadelphous stamens . Types of pollen grains, Fig.(43) Dolichos lablab, Fig.(44)Glycine max Fig.(45) Trigonella hamosa Fig.(46) Coronilla scorpiodes, Fig.(47) ) Coronilla scorpiodes, Fig (48)Medicago polymorpha and Fig.(49) Medicago minima.
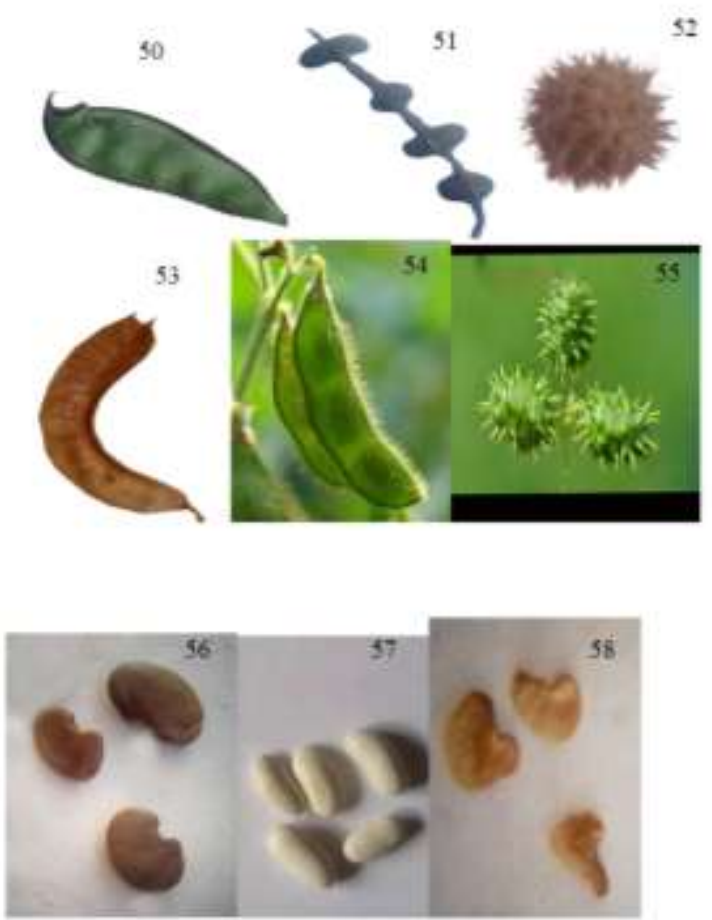

Figures : (50- 58) Showed Fruits and, seeds, Fig.(50)Dolichos lablab, Fig.(51) Erythrina caffra Fig.(52)Medicago intertexta, Fig.(53) ) Trigonella hamosa, Fig (54)Glycineo max ,Fig.(55) Medicago constricta, Fig.(56) Medicago intertexta, Fig.(57) Phaseolus vulgaris and Fig.(59) Trigonella arabica. 


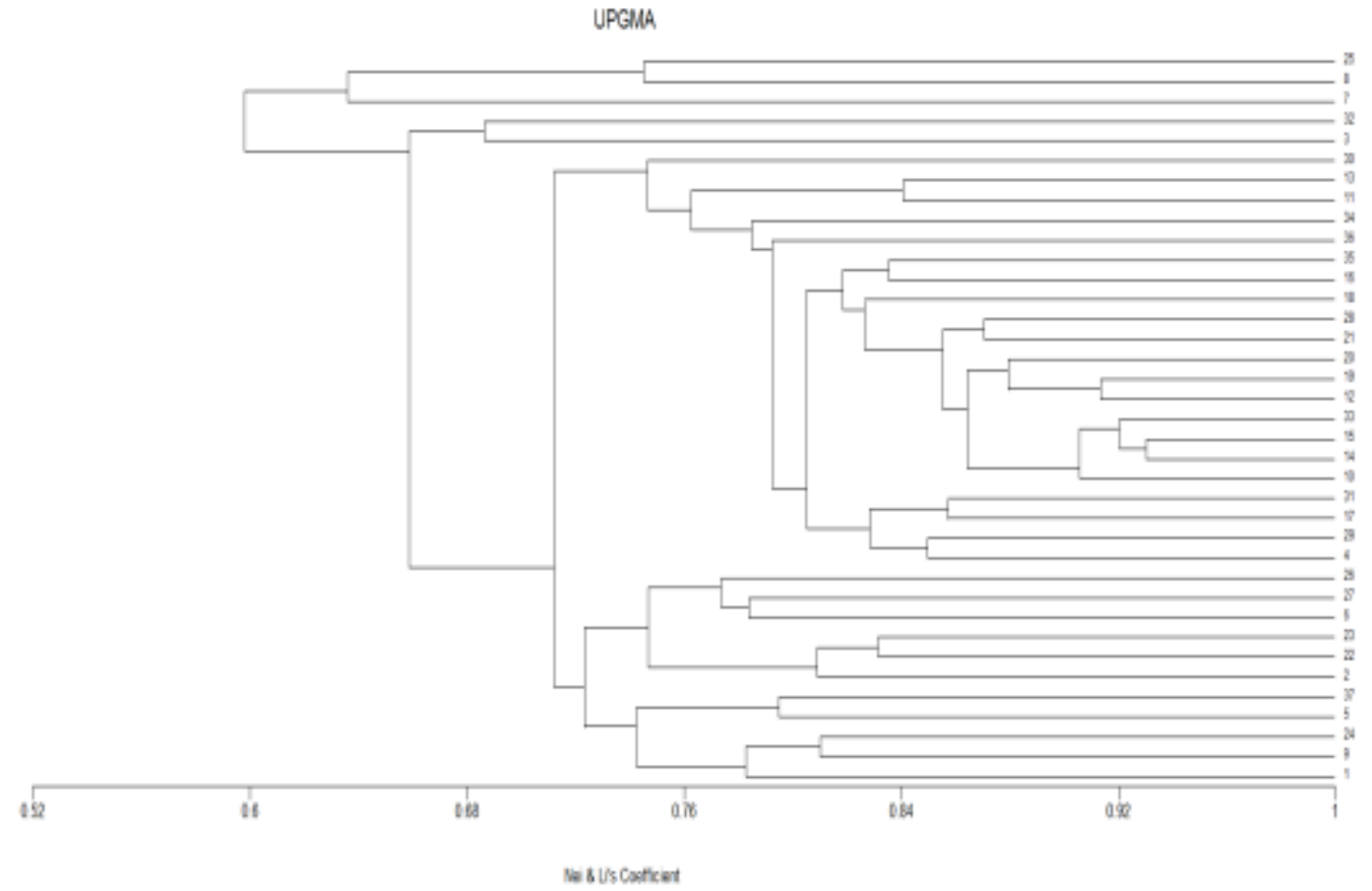

The results recorded in the data-matrix(Table, 3) used in numerical analysis program to determined the relationships between the studied samples. The producing dendrogram showed many interpretations as follows:

1 ) The studied samples divided into clusters A and B, the smallest one A includes only two genera Pseudarthia (Desmodieae) and Erythrina (Phaseoleae).

2 ) The cluster B divided into two clusters C and D, the smallest one C includes Trigonella arabica and Coronilla scropiodes each belonging to the same tribe Trifolieae.

3 ) The cluster D divided into two large clusters E and F, the cluster E includes 6 different genera Trifollium, Medicago, Melilotus and Trigonella (all belonging the same tribe Trifolieae); Cyamopsis (Indigofereae) and Tetragonolobus (Loteae).

4 ) The cluster $F$ divided into two clusters $G$ and $H$, The cluster $G$ includes 5 genera belonging to 4 tribes, Phaseoleae (Cajanus and Rhynchosia); Hedisareae (Ebinus), Trifolieae (Ononis) and Psoraleeae (Psoralea).

5 ) The cluster $\mathrm{H}$ includes 5 genera all belonging to tribe Phaseoleae (Dolichos, Glycine, Phaseolus and Vigna) except Argyrilobium belonging to tribe Genisteae.

\section{References}

Baily, H and Ethel, B.(1949). Aconcise dictionary of gardening, general horticulture and cultivated plants in north America. The macmillan company. New York. Pp :(24, 30, 86,127, 160, 177, 189, 206, $234,257,290,332,365,383,413,421,445,446,470,4$ 72,555,681 and 739).

Begum, A.; Rahman, O. and Begum, M. (2014). Stomatal and trichome diversity in Senna mill. from Bangladesh. Bangladesh J. Plant Taxon. 21 (1) 43 -51.

Boulos, L.(1999). Flora of Egypt. Al Hadara Publishing Cairo, Egypt. Vol. 1, 249 - 369.

Chauhan, Dipa; Daniel, M.(2011). Foliar micromorphological studies on some members of the family fabaceae. International Journal of Pharma \& Bio Sciences;Oct-Dec2011, Vol. 2 Issue 4, p603.

Diez, M. J. and Ferguson, I. K. (1996). Studies of the pollen morphology and taxonomy of the tribes Loteae and Coronilleae (Papilionoideae; Leguminoseae). 3, Coronilla L. and related genera and systematic conclusions. Review of Palaeobotany and Palynology. 94, 239 -257.

Franks, J. W. and Watson L. (1963). The pollen morphology of some critical Ericales. Pollen et spores 5:81-88.

Gunes, F. (2011). Pollen morphology of Lathyrus (Fabaceae) taxa in the Platystylis section from Turkey. Plant Syst E. Vol. 293, 75 -90.

Gupta, R. (2010). Medicinal and aromatic plants. CBS publishers and distributors, New Delhi. 
Marcia, M., Asaph, S., Rejane, M., Flavia. C., Karina, P. and Luiz, A. (2013). Anatomy of leaf and stem of Erythina velutina. Revista Brasileira de Farmacognosia Brazilian Journal of pharmacognosy. 23 (2): 200-206.

Meikle, R. (1985). Flora of Cyprus. BenthamMoxon Trust, Royal Botanic Gardens, Kew Vol., 2.

Miller, J. T., Murphy, D.J., Brown, G.K., Richardson, D.M., and Orozco, C.E. (2011). The evolution and phylogenetic placement of invasive Australian Acacia species. Divers Distrib. 17(5):848 -860

Özbek, F. ; Özbek, M. U. and Ekici, M. (2014). Morphological, anatomical, pollen and seed morphological properties of Melilotus bicolor Boiss.\& Balansa (Fabaceae) endemic to Turkey. AJCS 8 (4): 543 - 549.
Pandey, B. (2004). Taxonomy, anatomy, embryology (Including tissue culture) and economic botany. S. Chand and Company LTD, New Delhi-110055.98- 110.

Täckholm, V. (1974). Students Flora of Egypt. Edition 2 , Published by Cairo University printed by Cooperative Printing Company Beirut, 219 $-290$.

Takhtajan, A. (2009). Flowering plants second edition .Komarov botanical institute St. Petersburg Russia. 349 -351.

Tripathi, S. and Mondal, A. K. (2012). Taxonomic diversity in epidermal cells (stomata of some selected anthophyta under the order leguminales (Caesalpniaceae, Mimosaceae \& Fabaceae) based on numerical analysis: a systematic approach. International Journal of Science and Nature. Vol. 3. (4) $788-798$. 
دراسات نباتية مقارنة على بعض النباتات الثلاثية الاولق التى تنتمى لتحت الفصيلة الفراشية التى تنمو فى مصر

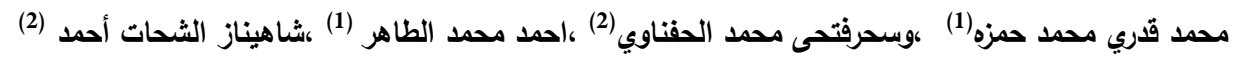

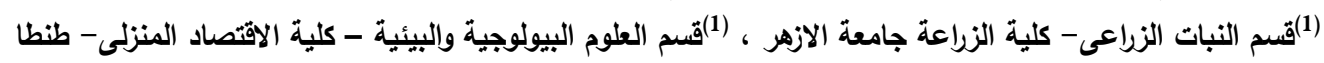

$$
\text { التخص العربى }
$$

اشتثلت الدراسة على الصفات الظاهرية لكل اعضاء النبات الخضريه والزهريه والثمريه، كما تم تشجيل بعض الصفات الدقيقه المأخوذه من صفات البشره في الوريقات مثل شكل الجدر ووجود او غياب البللورات في طبقة البشره وكذلك نوع الثثور وانثكال الزوائد المختلفه علي البشره. وتم

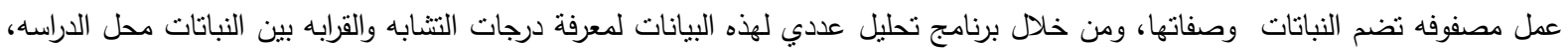

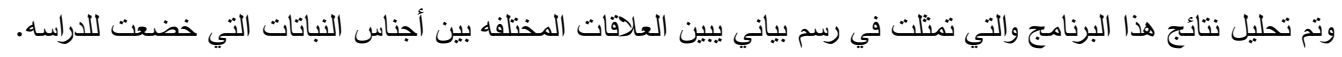

